E3 Journal of Business Management and Economics Vol. 7(2). pp. 072-088 August, 2016

Available online http://www.e3journals.org

ISSN 2141-7482 (C) E3 Journals 2016

DOI : http://dx.doi.org/10.18685/EJBME(7)2 EJBME-16-011

Full Length Research Paper

\title{
Comparative study on performance of islamic and conventional banks in MENA region
}

\author{
Asma SGHAIER $^{1 *}$, Habib SEKRAFI ${ }^{1}$ and Zouhaier MIGHRI ${ }^{2}$ \\ ${ }^{1}$ University of Sousse Tunisia. \\ ${ }^{2}$ LARTIGE, FSEG Sfax Tunisia.
}

Accepted 19 April, 2016

This study aims to measure the performance, profitability and efficiency of Islamic and conventional banks in the MENA region and its determinants. We use for this purpose the ROAA, ROAE to understand the overall profitability and econometric modeling for measuring profitability. The results show similar trends for both types of performance measurement. The banks category analysis reveals that conventional banks are outperforming Islamic banks. Despite technological changes experienced by the banking system in the MENA region, and the effectiveness of the banks in the MENA region is sensitive to the variables such as crisis, deposits, capitalization and including variables related to business lines.

Keywords: performance, technical efficiency, profitability, Islamic banks, risk management, MENA.

JEL: C12, C21, D21, G21, I32, L25, L31

\section{INTRODUCTION}

Islamic banks operate in more than sixty countries, but are mainly concentrated in the Middle East and in Asia (Zaman and Movassaghi, 2001). In most of these countries, the banking system is dominated by the conventional banking institutions. However, Pakistan, Sudan and Iran are the three countries which have Islamized their banking systems as a whole. Saudi Arabia is the largest market of Islamic finance in terms of size. It can be seen that the major part of the Islamic banking activity is concentrated in the Middle East, in particular in the countries of the Gulf. This region represents $85 \%$ of the total assets of Islamic Banks (Iqbal and Molyneux, 2005).

The evaluation of the performance of the banks is done by using some widely used indicators to measure the performance of banking, namely the financial ratios such as the performance of assets (ROA), the performance of the own funds (ROE), the net margin of interest (NIM),

\footnotetext{
*Corresponding Author Email: asma_sghaier1983@yahoo.fr
}

and the cost in relation to income (COSR). Most of the studies conclude that Islamic banks usually have better results compared to conventional banks. The evaluation of the performance of Islamic banks through a number of ratios gives fairly satisfactory results (lqbal and Molyneux, 2005).

As a general rule, a number of financial ratios are used to assess the performance of the banks. The main method of assessment of the internal performance is the analysis of accounting data. The financial ratios provide a broader understanding of the bank financial situation because they are formulated from the accounting data, balance sheets and financial statements.

In general, the results of research on the conventional banks have indicated that the internal and external factors of the profitability are important and contribute significantly to the profitability. Accordingly, a new study is necessary in order to assess their relevance and their application in an Islamic banking context since the two banking systems have practices different principles. This study seeks to achieve this objective and to determine 
the internal and external variables that influence the Islamic and conventional profitability.

We are going to conduct in this study an analysis of the profitability and liquidity for the two types of banks while using the financial ratios and the states of results, then we will estimate an econometric model which examines the impact of the bank profitability on variables such as liquidity, size, total credit and macroeconomic variables such as GDP and the ratio of inflation.

\section{Literature review}

Our theoretical analysis has allowed us to conclude that the Islamic banks and traditional banks have different structures of capital and profitability. We are based on the conventional arguments to explain these differences. The review of empirical literature also allowed us to identify the classic determinants (internal) which affect the profitability and efficiency of banking and could explain the differences which exist between the Islamic banks and conventional ones.

Several empirical studies have focused on the comparison of the profitability of Islamic and conventional banks. Some works reveal that the Islamic banks are more profitable (Olson and Zoubi, 2008; Hassoune, 2002; lqbal, 2001; Rosly and Bakar, 2003). However, other empirical studies found different results (Metwally, 1997; Ahmed and Hassan, 2007; Kader and Asarpota, 2007).

Olson and Zoubi (2008) compared 28 conventional banks to 16 Islamic banks in the region of the Gulf on the period 2000-2005. Their study confirms that the Islamic banks are more profitable. They show that the profitability of the assets and the profitability of equity are significantly higher in Islamic banks. The ratio of net margin (NIM) is two times higher for the Islamic banks than the conventional banks and the difference is significant. Their study also reveals that the Islamic banks pay more dividends to their shareholders than traditional banks. The study of Iqbal (2001) revealed that the Islamic banks record higher profitability of own capital and profitability of assets compared to a reference sample of conventional banks for the period 1990-1998. The study focused on 24 banks from which 12 are islamic from 10 different countries. The study conducted by Rosly and Bakar (2003) has also shown that the profitability of the assets and the profit margin of Islamic banks are higher in Malaysia during the period 1996-1999. However, other empirical studies found different results (Metwally, 1997; Ahmed and Hassan, 2007; Kader and Asarpota, 2007). Metwally (1997) Compared a sample composed of 30 banks, 15 of them are Islamic during the period 19921994. Its results reveal that the Islamic banks do not seem to be very different from their conventional counterparts in terms of assets profitability and the rate of return on the deposits. Based on this empirical literature, the difference in profitability between Islamic banks and conventional ones could be explained by the difference of these determinants profitability between the two types of banks. ${ }^{i}$

Several researchers have analyzed the role of Islamic banks and this in the framework of 18 countries, between 1993 and 2004 (Čihák and Hessen, 2008). They analyze the financial stability by using the model z-score. Their results indicate an interesting difference in the stability of small and large Islamic banking institutions. It has been found that the smaller banks have proved to be much more stable than those operating at a larger scale. The proposed explanation is that the Islamic banks tend to have difficulties in the monitoring of credit risk when the company becomes larger and therefore more complex. The small banks have a tendency to concentrate on lowrisk investments, while the large Islamic banks perform more risky financing (PLS).

A multitude of authors has analyzed the performance using data from several countries, such Molyneux et al. (1992), Demirgüç-Kunt et al. (1999), Abreu et al. (2002), Goddard et al. (2004) and Athanasoglou et al. (2006), others, such Berger et al. (1987) (the banking system in the United States), Barajas (1999) (Colombia), Mamatzakis and Remoundos (2003) (Greece) and Garcia Herrero et al. (2009) (China) have studied some specific countries data. The analysis of the banking performance determinants; were a fundamental component of research in many countries; have focused on the two categories of banks, on the one hand Islamic (Sudin, 1996; Sanusi and Ismail, 2005; Bashir and Hassan, 2003; Bashir, 2003; Srairi, 2008) and on the other hand, conventional ones (Ben Naceur and Goaied, 2003; Pasiouras and Kosmidou, 2007; Athanasoglou et al., 2008; Rouisi et al., 2008; Srairi, 2008; Olson and Zoubi, 2011; Dietrich and Wanzenried, 2011).

The empirical investigations are based on internal factors related to the specific characteristics of the banks as well as external factors related to the industry and banking with the economy. Generally, the internal factors are related to the management such as the management of the risk, the management of costs, the liquidity, capital, size, etc. Concerning the external factors, they are not controlled directly by the management but by other factors such as: the factors of regulation, competition, concentration, the share of the market, inflation, real GDP and the demand for currency, etc.

Overall, the internal factors which are the most used and which have significant effects on the profitability are: size, capital structure, liquidity of the bank assets, credit risk and the volume of deposit. The external determinants are : competition, concentration, the share of the market, inflation and the real GDP. According to Hasan and Dridi (2010), the crisis has given to the Islamic banks the opportunity to demonstrate their resilience, it has also revealed serious difficulties which must be remedied in order to perpetuate their growth. i 
Absence of solid infrastructure for the management of liquidity risk: Islamic banks having greater recourse to individuals' deposits than conventional banks, they have more stable sources of funding. Meantime, they have serious difficulties in the liquidity management mainly:

- A bit profound monetary market because of the low number of participants;

- The absence of instruments that can be used to guarantee the loans or be rediscounting at the counter of the central bank.

Some Islamic banks have responded by presenting a balance sheet excessively liquid (that is to say with more liquid assets that generate a lower return to loans and to a good number of titles), which sacrifiy the profitability. The Islamic institutions have $40 \%$ of liquidity more than their classical counterparts (Khan and Bhatti, 2008). This approach of the liquidity has certainly limited the risks during the crisis, but this is not an ideal solution in normal times. The creation in October 2010 of the International Society of Islamic liquidity has been a step toward a strengthening of the capacity of the Islamic banks to manage the international liquidity. This effort must continue. More generally, the monetary authorities and regulation must ensure the neutrality of the liquidity's infrastructure regardless of the type of bank (for example, developing the sovereign Sukuks, the Islamic obligations, in addition to the conventional obligations and certificates of deposit) and its ability to withstand the difficulties is highlighted during the crisis.

Need of an institutional framework conducive to the establishments in difficulty: The existence of a mechanism of cooperation between the supervisory authorities of the Islamic banks in difficulty and the interior of the country, and between them, is essential to prevent any contagion beyond national borders.

\section{Absence of harmonization of regulatory standards and Accountants: This has been one of the main problems of the control authorities and actors of the market during the crisis. A problem exacerbated by the lack of uniformity of contracts or financial products. The standards governing the operation of Islamic banks remain fragmented, despite the initiatives of the organization of accounting and audit institutions of Islamic finance. The Office of the Islamic financial services aimed to create international guidance for this sector.}

Insufficient expertise: The level of expertise within the sector of Islamic finance has not followed the rapid development of this sector. The Islamic bankers as well as the authorities of control and supervision must know the conventional finance in the same way as the different aspects of the Islamic Shariah, given the level of growing sophistication of Islamic financial products. The lack of specialists also impedes the invention of new products and could hamper the good management of risks specific to the sector. During the financial crisis, the Islamic banks have made their evidence. However, the crisis has highlighted the development remaining to be done. With the reform of the Financial Regulation in progress at the global scale, the time is riped for the Islamic banking control authorities to meet the challenges of the sector.

We will look in our study to internal and the external characteristics. Our choice is justified by the fact that these determinants take into account the specificities of the bank, so we can detect the character "Islamic" of Islamic banks.

First of all, the relationship between the variable size (in terms of total assets) and the variable profitability are an important part of the theory of the firm. In fact, it poses the problem of optimal size of a firm which maximizes the profitability. The impact of size on the banking profitability diverges according to the studies. Dietrich and Wanzenried (2011), Rouisi and al (2010) show that the size positively affects the profitability. Bashir and Hassan (2003) found the same result for the Islamic banks. This may be explained by the fact that the banks of larger size have more possibilities to grant a more important volume of loans and financing to their clienteles compared to banks of small sizes, which increases their profitability of assets. In addition, major banks tend to have the possibility of more diversified portfolios of banking products compared to small banks which reduces their risk. Economies of scale can also result in a larger size. These conditions cause more operational effectiveness for the banks of large sizes. Pasiouras and Kosmidou (2007), Srairi (2008) and Sanusi and Ismail (2005) show that the size negatively affects the profitability. If the bank's size exceeds at a certain level, profitability will decrease. In contrast, the study of Athanasoglou and al (2008) reveals that the size of the bank has no effect on the profitability. This result shows that the banks of small size are usually trying to grow more quickly, even to the detriment of their profitability. In addition, the banks newly created are not particularly profitable, even not profitable at all, in their first years of operation since they put more emphasis on the increase in their market share, rather than on the improvement of their profitability.

The liquid assets also determine the profitability of banking. The excess liquidity negatively affects the banking profitability because of the opportunity cost of the money inactive. The Liquidity plays a major role in the management of a credit institution. The empirical studies confirm the negative impact of the liquidity of the assets on the profitability of Islamic and conventional banks (Srairi, 2008; Sanusi and Ismail, 2005; Bashir and Hassan, 2003; Bashir and Hassan, 2003; Bashir, 2003; Dietrich and Wanzenried, 2011; Rouisi and al, 2010; Pasiouras and kosmidou, 2007; Naceur and Goaied 2003). The ratios of the more used to measure the liquidity of the assets are the ratio of "total loans/total 
assets" and the ratio of "liquid assets/total active" (i.e., both the ratios $\mathrm{ROA}$ and $\mathrm{ROE}$ ).

Other studies found that the credit risk negatively affects the profitability of banks. Olson and ZOUBI (2011), Srairi (2008), Rouisi and al (2010) and Dietrich and Wanzenried (2011) show that the credit risk negatively affects the profitability of the assets of conventional banks. The capital ratio also determines the profitability of banking. The financial theory suggests that the firms the more indebted realize higher profitability of own capital. The impact of the capital ratio on the banking profitability is different according to the studies. Olson and ZOUBI (2011) show that the level of own capital negatively affects the profitability of own capital. Rouisi and al (2010), Athanasoglou and al (2008), Olson and Zoubi (2011) show that the capital has a positive effect on the profitability of the assets of the banks and the net margin. The study of Olson and ZOUBI (2011) reveals that the volume of deposits positively affects the profitability of the assets of Islamic banks. The study of Dietrich and Wanzenried (2011) reveals that the volume of deposits has a significant impact on the negative profitability of assets and the ratio of net margin of conventional banks.

This effect is noticed primarily during the period of crisis. The Swiss banks have not been able to convert the significant amount of deposits in the assets that generate income during the period of the crisis. Based on this empirical literature, the difference in profitability between Islamic banks and conventional could be explained by the difference of these determinants of profitability between the two types of banks.

\section{SAMPLE, VARIABLES AND RESEARCH METHODOLOGY}

\section{Sample}

In our construction of the sample, we have considered MENA countries for which the banking data are regularly published for the period 2005-2011.

The results of research on Bankscope have given us 158 Islamic banks. The unavailability of the data has forced us to limit our analysis to 52 Islamic banks and 132 conventional banks. We have retained only the banks $100 \%$ Islamic. We have eliminated the "Islamic Windows". The banks classified "Islamic" by "Bankscope" but do not have an advisory committee of Shari'a on their Internet sites are also eliminated.

The availability of useful statistical data, constitutes a necessary condition to conduct empirical and analytical studies in any field. Our study focuses on the case of Islamic banks. The observation of this object of study is not an easy undertaking because of the non availability of statistical data. First, there is little databases, specialized or general, providing information on the Islamic banks.
The famous databases, such as DataStream or Bankscope, certainly, provide some data on these institutions (ROA, ROE,...), but a few variables needed in our study were not available for some banks. Secondly, the annual reports of banks are not always available. Even the major Islamic banks do not have a complete series of annual reports.

There are limits related to the lack of standardization of financial statements of Islamic banks. In effect, these banks are not yet using a unified accounting and unique code of communication and disclosure of financial statements (like the conventional banks). As well, annual reports can vary considerably from one bank to another, both in their presentation and in the terminology used. For this reason the choice of our sample is limited even a period according to the availability of data and annual reports.

\section{The period of the study}

The initial idea of this research was to investigate a sample of Islamic banks on a period of at least ten years. In effect, the data on the conventional banks are available and for a large period. Similarly, this period of study makes our analysis rich enough and allows us to achieve results that are representative of the strategies and current trends of banks. Several elements have led us to come back on this choice.

First of all, most of the Islamic banks have been created only recently, in the years 2000 . Several of them have not launched their activities for than 2005. In addition, for banks which existed before the year 2005, several annual reports were missing; which elsewhere indicates the problem of the transparency of Islamic financial institutions. The preceding elements have forced us to limit period of study between 2005 - 2011. This period is of a great interest.

The period of our study can be considered as relevant since when we compare our analysis to other research dealing with the Islamic banks, we find it among the longest (7 years). The other researches do not exceed a single year, two or three years at the maximum. In addition, the period 2005-2011 has experienced several important financial events including:

- 2007: The financial crisis has recorded tensions on liquidity;

- 2008: The liquidity crisis purely financial, evolves toward a crisis of confidence, paralyzing all banks toward a crisis of the real economy;

- 2009: The subprime crisis has spread to all sectors of the Finance and the real economy, the first measures of the public authorities arise to stem the crisis;

- 2010: the influx of cash fact fear the outbreak of new bubbles in the real estate, the scholarships, the borrowing of States it is the financial crisis in 


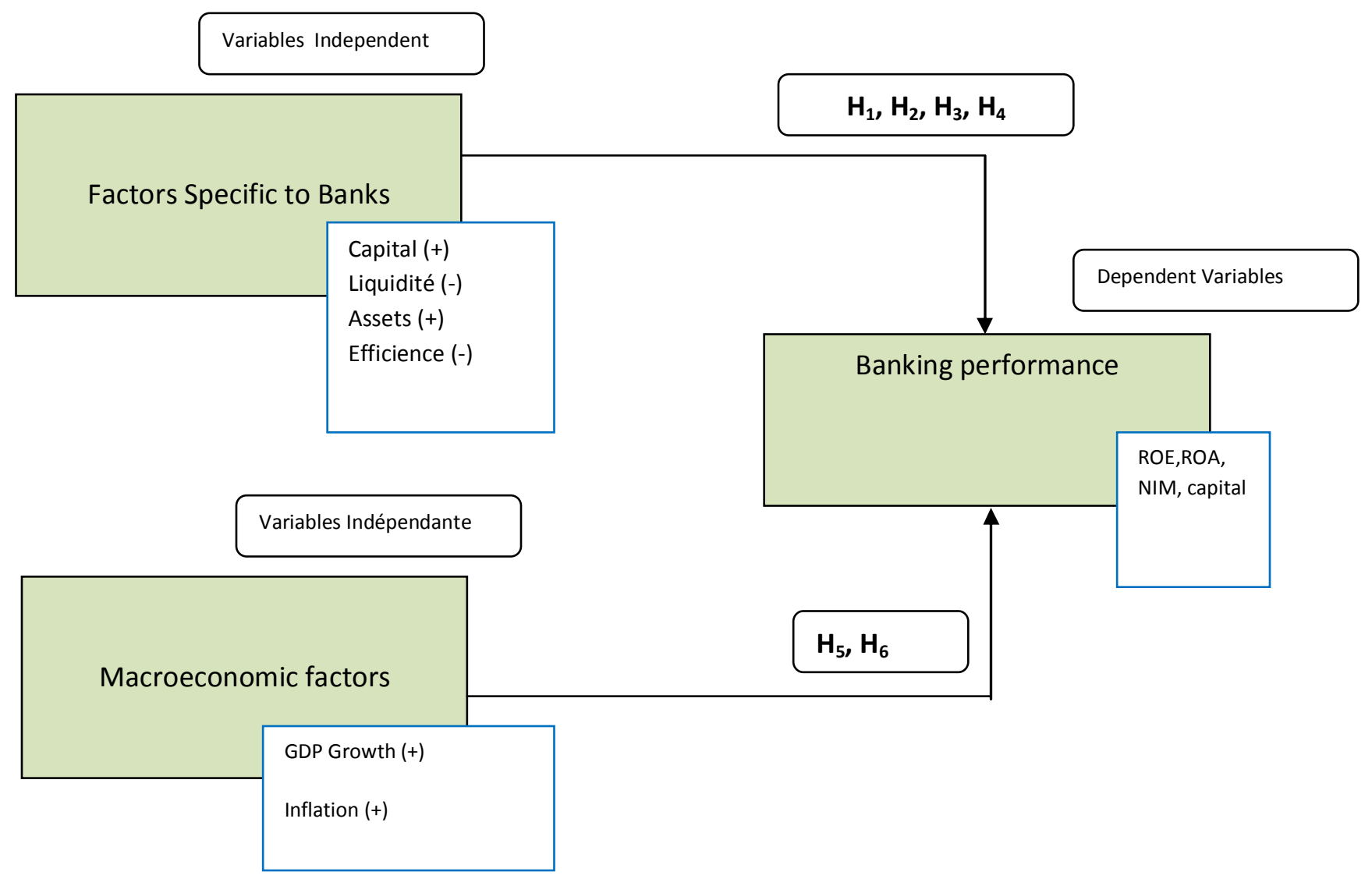

Figure 1. theoretical framework of assumptions of our research

the background (Boyer.r, Dehove.M and Plihon.D, 2010).

Our analysis focuses on the period of crisis of "Supbrimes" (2005-2011): The economic crisis which has shaken the finance and more widely the world economy between 2007 and 2010. In this context, several authors are interviewed on the performance, and the potential of Islamic banks. They have revealed that they have effective instruments to build a sustainable financial system with less debts than the conventional finance (Fredj, 2011) and it is today a source of reform of the conventional finance (Walter, 2008; Herlin, 2009). It has been able to escape the crisis (Boumendjel, 2009; Boumendjel, 2009; Rezaïguia, 2009; Plantrou, 2011; Hamza, 2012; Guermazi-Bouassida, 2012; Fredj.I, 2012; etc.) and even, otheres have led to the conclusion that the Islamic finance could be an alternative to the conventional finance (Mostefa, 2009; Latrache, 2010; Jwabeur, 2010; etc).

\section{Source of data}

We have had recourse to the database " Bankscope" to collect accounting, financial and managerial data about the banks of our sample. This basis for the quasi-totality of banking firms in the world. It includes the balance sheet data, the states of results, the activity reports, annual reports and abstract reports of the banks in question. These various reports are downloadable directly from the Internet site of the database. The data that we have collected cover the period 2005-2011, 7 years.

For our sample, we have selected all banks for which the data are available and we then excluded the firms for which the data are missing. After reprocessing, our sample consisted of 184 banks (132 conventional banks and 52 Islamic banks) in 11 countries in MENA region. For our period of analysis of 7 years, we have collected 1288 observations. These panel data allow us to take advantage of the double individual dimension and temporal available information. We note that, all amounts are expressed in thousands of US dollars (MUSD). To convert currencies has used the exchange rates of the $31 / 12$ of each year.

\section{Research hypotheses}

The model of banking profitability will be estimated for the two types of banks. For this, we will first test the assumptions below (see figure 1) 
Table 1. Definitions, notation and expected effect of the explanatory variables of the banking performance

\begin{tabular}{|c|c|c|c|}
\hline The variables & Description & Marking & Expected effect \\
\hline \multirow{2}{*}{ A. Dependent variable } & Return on average assets & ROA & \\
\hline & Return on Average Equity & ROE & \\
\hline \multicolumn{4}{|l|}{ B. Independent Variable } \\
\hline \multicolumn{4}{|l|}{ Specific to banks } \\
\hline Efficiency & Cost to Income Ratio & COSR & The negative \\
\hline Liquidté & Net loans to total assets & Nthe & The negative \\
\hline \multicolumn{4}{|l|}{ Macroeconomic policy } \\
\hline GDP Growth & GDP Growth & GDP & Positive \\
\hline
\end{tabular}

Sources: MELATY BINTI Ghazali, 2008: "The bank-specific and macroeconomic determinants of Islamic Bank Profitability: Some International Evidence."

- $\mathrm{H1}$ : The performance is positive and the relationship with the ratio of EA is significant.

- $\quad \mathrm{H} 2$ : The LLR ratio (loan loss reserve) is positive and the relationship is significant with the performance measures.

- $\quad \mathrm{H} 3$ : The performance is significantly negative with the COSR (cost to INCOM Ratio).

- $\quad \mathrm{H} 4$ : a significant and positive relationship between the net ratio loan, total assets (NLN) and the ratio of performance.

- $\quad \underline{H 5}$ : a link significantly positive between performance and the GDP growth.

- H6: a link significantly positive between performance and the inflation.

\section{Model and variables:}

The mathematical formulation of the model is the following (see table 1):

\section{Profitability $_{i, t}$}

$$
\begin{aligned}
& =\beta_{0}+\beta_{1} L L R_{i, t}+\beta_{2} E A_{i, t}+\beta_{3} \operatorname{COSR}_{i, t} \\
& +\beta_{4} N L A_{i, t}+\beta_{5} G D P_{i, t}+\beta_{6} C P I_{i, t}+\mu_{i, t} \\
& +\varepsilon_{i, t}
\end{aligned}
$$

With:

$>$ Dependent Variable:

$>$ Profitability $=$ ROA or ROE.

$>$ Independent variables:

$>\quad \mathrm{LLR}=$ loan loss reserves to gross loan ratio

$>\mathrm{EA}=$ Total equity to total assets ratio

$>\mathrm{COSR}=$ Cost to Income Ratio

$>$ Nthe $=$ Net loans to total assets ratio

$>\mathrm{GDP}=\mathrm{GDP}$ growth rate

$>\mathrm{CPI}=$ Consumer Price Index

\section{RESULTS AND INTERPRETATIONS}

\section{Analysis of the profitability and liquidity of the two types of banks:}

The following chart traces the evolution of the index (NIM) of the banking sector in the countries of the Gulf (see figure 2).

We note that the ratio of NIM has marked a decline since the 2009; while this ratio has increased since 2008 for the conventional banks has started to decrease since 2011. Table 2 outlines the statistics of profitability ratios and shows us the evolution of profitability ratios as well as the variables of liquidity.

The Islamic finance has been a fast-growth sector in the MENA region (as shown in table 2). The assets, deposits and the indicators of funding have all increased rapidly in the region between 2005-2011. However, the rate of growth has significantly decreased in the period 2007-2008, it may be justified by the financial crisis. Even with this moderation that affects the Islamic banking performance, it remains higher than the conventional banks during the same period. The negative effect of the crisis is passed on to the Islamic banks in 2010. To locate the profitability of Islamic banks, we have adopted a methodology in which we compare the average of the ratios of profitability and liquidity of Islamic banks in a country with its similar in another country. The key ratios selected for this analysis are the following: assets, equity, EA, ROA, ROE, NLAR, COSR, LaCDSF.

The ratio of return on assets (ROA) significantly decreased for the Islamic banks in all countries of MENA and this from the year 2007 compared to 2006; where this value has increased up to reach $-0.7 \%$. Since 2006, the ROA has been declined in most countries except 


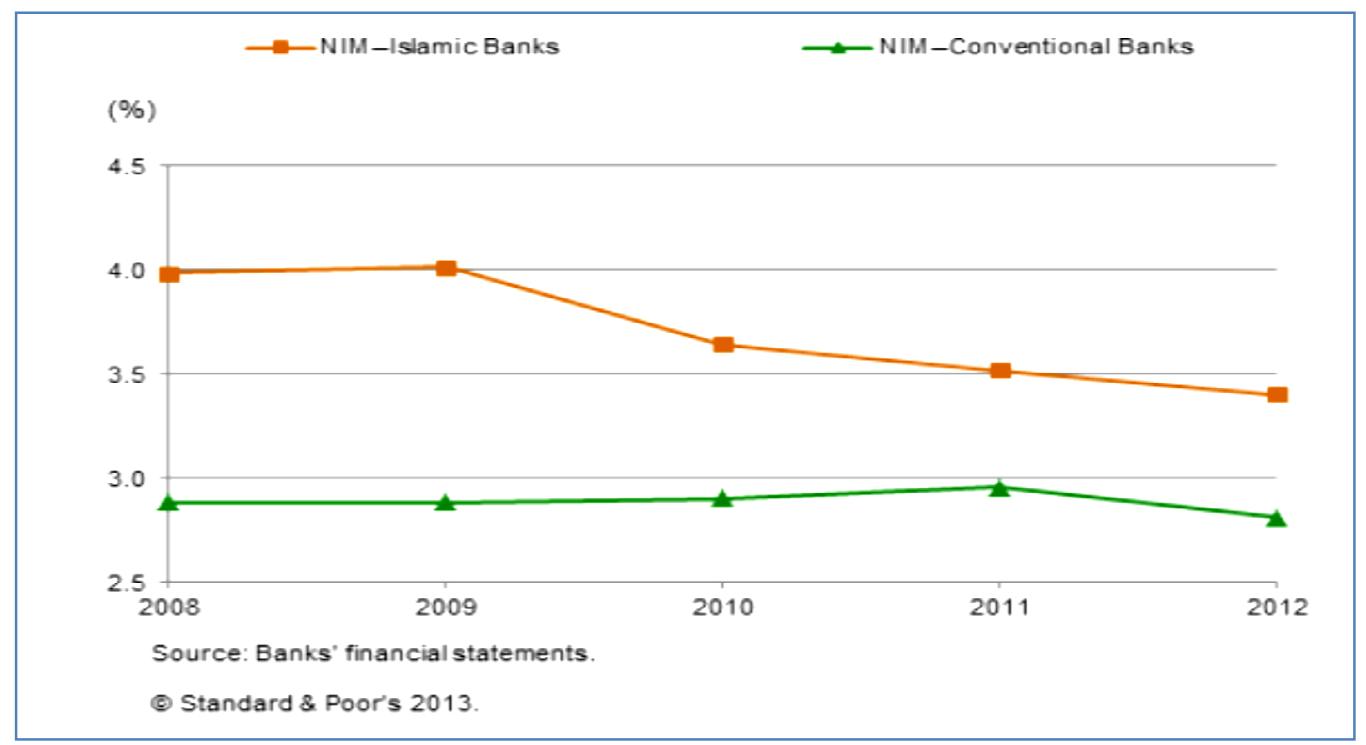

Figure 2. Evolution of the index (NIM) of the banking sector in the region CCG (Source: Timucin Gear, Emmanuel F Volland and Nadim Amatouri 2013)

Table 2. The statistics of (The / TA), EA, (ROA) and (ROE) By years

\begin{tabular}{lcccccccc}
\hline & Assets & Equity & EA & ROA & ROE & NLAR & COSR & LaCDSF \\
\hline & & & \multicolumn{7}{c}{ Conventional banks } & & & \\
\hline 2005 & 6030842,16 & 753264,96 & 12.49 & 2.74 & 14.05 & 46.04 & 47,01 & 54,53 \\
2006 & 7465520,25 & 889124.57 & 11,91 & 2.33 & 15.43 & 47,22 & 49,85 & 53.90 \\
2007 & 10205989,05 & 1177359,90 & 11.54 & 2.05 & 11.61 & 48,80 & 49.32 & 51.79 \\
2008 & 11274716,54 & 1254070,89 & 11,12 & 1.57 & 9.93 & 50.89 & 55,97 & 51.50 \\
2009 & 21391264,88 & 2375420,69 & 11,10 & 1.70 & 11.76 & 51.35 & 55.64 & 49.38 \\
2010 & 23724636,05 & 2674663,16 & 11,27 & 2.01 & 15.29 & 60,54 & 70.49 & 62.13 \\
2011 & 27535294,64 & 2671171,01 & 9.70 & 2.34 & 17.75 & 77.34 & 95.07 & 79.67 \\
\hline & & & & \multicolumn{7}{c}{ Islamic banks } & & & \\
\hline 2005 & 2337261,51 & 483884,13 & 20.70 & 5.90 & 19,55 & 47.30 & 48.86 & 61,17 \\
2006 & 2921718,96 & 621747,76 & 21.28 & 5.04 & 18.28 & 44.35 & 52.76 & 71,54 \\
2007 & 3937317,02 & 807086,21 & 20,50 & 5,30 & 18,54 & 44.24 & 45,86 & 68,86 \\
2008 & 4664139,13 & 901032,31 & 19,32 & 2.00 & 11.20 & 44.65 & 60.07 & 56,80 \\
2009 & 22040953,87 & 3168920,08 & 14.38 & 0.26 & 4.85 & 42,31 & 65,83 & 54.41 \\
2010 & 23403963,56 & 3292779,35 & 14.07 & -0.36 & 3.55 & 41,13 & 70.62 Item & 69,42 \\
2011 & 23431610,73 & 3296987,91 & 14.07 & $-0,70$ & 2.82 & 41.02 & 73,44 & 59,53 \\
\hline
\end{tabular}

Jordan, Qatar and the United Arab Emirates where it had slightly increased in 2007 before falling again in 2008.

However, in 2009 the ROA has greatly decreased in most of the countries, but in a very divergent. Way it has reached $-7 \%$ to Bahrain and $-2.1 \%$ in Kuwait. It decreases, but remains positive at $1.7 \%$ in the E.A.U and $-1 \%$ in Saudi Arabia. However, it has increased by more than $4 \%$ in Qatar during the same year. By contrast, the ROA has increased in the conventional banks and this was from the year 2006 up to 0.234 with a low decrease between the period 2005 and 2006.

The use of the assets is defined by using the ratio of the equity/total assets (EA) which was positive but in progressive decrease from 2006 in most of the countries 
in our sample and this was true for the two types of banks. The rate of use of the assets E/A for the MENA region was $12.5 \%$ for the conventional banks and $20.7 \%$ for the Islamic banks in 2005. For the Islamic banks, a high rate of use of the assets is an indicator of the nature of participation in the profits for the deposit contract between the Islamic banks and their depositors (Mudharaba accounts-based).

The rate of use of the assets has increased in 2009 in most of the countries. It has strongly increased in Saudi Arabia (75.6\%) and Bahrain (73\%), but decreased significantly in the United Arab Emirates (68\%). This indicates a prudent attitude of Islamic banks after the crisis of the real estate market. The increase in the proportion of liquid assets and the decrease in the overall demand for credit have contributed to reduce the use of assets by Islamic banks in the United Arab Emirates. On the contrary the banks in Saudi Arabia and Bahrain have a growth in their banking sectors.

The ratio of net operating income in relation to the total assets (ROA) of Islamic banks was very variable depending on the country. The lowest ratio, among the Islamic banks, was raised in Saudi Arabia. We also note the strong decline in this ratio in the Islamic banking sector of Bahrain in 2009.

The performance of equity ( $R O E)$ is measured by the net profit of the total of own funds. It varies in a remarkable way in the conventional banks and even in the Islamic banks, but in general it is remained high even during the global financial crisis, and despite that the world classic banking sector has been hit hard. For example, the ROE of Islamic banks in the United Arab Emirates in 2008 is approximately $15 \%$, and it was the highest value in the region compared to other countries. During the same year, the value of ROE of the Islamic banks of Bahrain has been estimated by $7.2 \%$, Egypt approximately $0.1 \%$, Jordan $14.4 \%$, Kuwait $8.2 \%$, Qatar $11.9 \%$, Saudi Arabia 10.7\%, and Yemen 7\%. However, the situation has changed in the MENA region in 2009, when the ROE of Islamic banks has declined in most countries and in a remarkable way.

The variation of the data of the ROE ratio for the years 2005 to 2011 shows us a convergence model according to the country by years. This may be due to the moderating effect of the financial crisis; or it may reflect a growing integration of the competition between these countries. The ROE became negative to Bahrain and Kuwait while it is positive in the other countries despite its decrease. The Islamic banks in Qatar have experienced an increase in ROE. The question which arises is "Why the Islamic banking sector has behaved differently in different countries during the stressful period in 2009 while they were converging in the performance sooner? "(Salman, 2011) $)^{\mathrm{iii}}$. It is a question of an important research that may give an idea of the importance of various aspects of the stability and growth of Islamic finance which requires a full-fledged research in the future.

The value of ROE is negative in Bahrain which leads us to say that a large number of small banks with low capital have reduced their ability to diversify to reduce their capacity to absorb the losses. In the case of Kuwait, the ROE is also negative and this is despite the strong capitalization of banks (Salman, 2011). The best performance is marked in the United Arab Emirates in 2009 compared to that found in Bahrain and Kuwait. This may be explained by the support to the areas by liquidity provided by the central bank of the United Arab Emirates.

Another dimension of the evaluation of performance is carried out through the examination of the structure of revenues and expenditures. The results show, for some countries, the distribution of total income in operating revenue and non-operating and the distribution of total income in its uses: fresh, provisions and profits before taxes.

The proportion of net operating income in the total income is the highest for Saudi Arabia and the lowest for the Bahrain. Operating expenses as a percentage of the higher incomes are marked in Bahrain and the lowest in Saudi Arabia. This may be due to economies of scale achieved by the largest Islamic banks in Saudi Arabia, by opposition to those of smaller sizes in Bahrain. Thus, liquidity saves the greater value to the United Arab Emirates and the smallest in Bahrain. These structures of revenues and expenditures have implications on the profits. The profit before tax was the highest in Saudi Arabia and the lowest in the water.

The results also show the yields on assets of Islamic and conventional banks. The data show that the ROA of the two categories of banks are positively correlated. In 2007, the yields of the assets of the conventional Bank were higher than that of the Islamic Bank in four countries and were nearly equal in the other countries. In addition, there was a great diversity in the performance of assets between countries in 2007. However, this variation is reduced in 2009 in all countries and both the Islamic and conventional banks.

In 2007, the ROE of the Islamic Bank was higher than the performance of the own capital of the conventional bank. In addition, the variation in ROE of the conventional bank has increased in 2008 compared to 2007, while it declined in the Islamic banking sector.

The ratio of operating result to the assets of the Bank has been higher for the conventional banks compared to the Islamic banks in 2007, and it remained high in 2008 and up to the end of our period of study. However, for this ratio, the difference between Islamic finance and conventional is reduced in 2008 compared to the previous year.

The ratio of the assets of the bank (which is the same as the rate of use of the assets) was significantly higher in the Islamic banking sector than in the conventional 
banking system in many countries in the course of 2007 and it has remained as well in 2008.

\section{Modeling and analysis of the banking performance}

According MELATY BINTI Ghazali (2008), the performance of the assets (ROA) is considered one of the most relevant measures in order to measure the performance of the banking sector. It shows a capacity acquired by the Directorate to acquire deposits at a reasonable cost and to invest in profitable investments. This is reflected in the ROA, since the investments and loans are the largest part of the bank assets, while the interest on the loans are similar to the greater part of the turnover and the performance of the bank (Simpson and Kohers 2002). Some studies even go so far as to argue that ROA is the "financial indicator the more important in the banking sector" (Reger, Duhaime and Stimpert 1992 : 195). The ROA has the advantage to be used for small businesses; which have a very small base of own capital; in this case the ROE can be a little misleading by report to ROA (Reger and al, 1992). ROA is considered as being strongly correlated with ROE in the banking sector, where both give the same indication of the variation of the financial performance, but differ in magnitude (Simpson and Kohers 2002, Castelli, Dwyer and Hasan 2006, Karr 2005).

Houcem Smaoui and Ines Ben Salah in their work provided a new definition of "Profitability of Islamic Banks in the GCC region", the performance of equity (ROE) as one of the measures of performance the most commonly used in the banking system. It can be used in most of the researches on the financial performance as well as reports of analysts and the financial results of the company (Lindblom and Von Koch 2002). It is also regarded as a simple method to calculate and measure past performance while giving quite a good indicator of the prospects ROE (Wilcox, 1984). Hopkins et al. (1997) asserts that the most reliable measure of the performance of any financial institution is the ROE. It also contributes to compare banks whatever their size and their different structures. The use of this ratio as a measure, is based mainly on the assumption of "creating value for the customer is positively correlated to the financial performance [measured in RE] of the Bank" (Lindblom and al, 2002, p 48).

The limits of the use of the ratio of ROE is that this measure may lead to erroneous results due to differences in size between the undertakings in respect of the credit risk (Lindblom et al., 2002). Another limitation is the fact that minor differences in the account types are ignored, such as the different types of deposits or loans, or change the benefit margins (Avkiran 1997). Another limit of ROE is that it does not take account of the cost of capital in its calculation (Fraker 2006).
Given these limitations, we propose in this paper an econometric modeling different from the performance. The Panel data, by their double individual dimension and temporal, offer new prospects in applied economics. In particular, they make possible a better representation of the behavior of individuals (regions, countries, etc..). It has become customary to specify the econometric models on microeconomic foundations, and work on panel data. Also it is important to well identify the characteristics. In effect, the richness, the density of this information generate benefits to this type of modeling.

According to the literature review, the variables most used are grouped under various categories:

- The variables of profitability: ROA, ROE.

- Variables of capital adequacy: equity/total assets, equity/liabilities and equity/loans.

- Variables of liquidity: interbank Ratio, Net Loans/total assets, net loans/deposits and Short term funding, Liquid Assets /dep and ST Funding and liquid assets/total Dep.

- Variables of efficiency: Cost to Income Ratio and recurring earning power.

- Variables concerning the quality of assets: total assets and loan loss reserve/Gross Loans.

We note that all of the explanatory variables in the model before are delayed for a period, which considerably reduces the possibility of their being endogenous to the measures of profitability. This model of profitability is estimated by using the estimating technique of Prais-Winston which produces the panel corrected errors standards (PCSE) and considers the panel data linear. During the calculation of standard-error and the estimation of variance-covariance, the disturbances are assumed to be heteroscedastic and simultaneously correlated in this panel. In econometrics, the estimate of Prais-Winsten is a procedure designed to take into account the correlation of Time Series of the type of $\operatorname{Ar}(1)$ in a linear model. It is a modification of Cochrane-Orcutt estimate in the sense that it does not lose the first observation and led to greater effectiveness. Patrick Sevestre (2002) considers the following model: $y_{t}=\alpha+X_{t} \beta+\varepsilon_{t}$

With:

- $y_{t}$ : represents the time series at time $t$,

- $\beta$ : a vector of coefficients,

- $X_{t}$ : is a matrix of the explanatory variables,

- $\varepsilon_{t}$ : is the error term

- The error term can be correlated in time series as follows:

- $\varepsilon_{\mathrm{t}}=\rho \varepsilon_{\mathrm{t}-1}+e_{\mathrm{t}},|\rho|<1$; With $e_{\mathrm{t}}$ : represents the white noise.

In addition to the transformation of the Cochrane-Orcutt procedure is:

$\mathrm{y}_{\mathrm{t}}-\rho \mathrm{y}_{\mathrm{t}-1}=\alpha(1-\rho)+\beta\left(\mathrm{X}_{\mathrm{t}}-\rho \mathrm{X}_{\mathrm{t}-1}\right)+\mathrm{e}_{\mathrm{t}}$

For $t=2.3, \ldots, T$, the method of Prais-Winsten made a reasonable transformation for $\mathrm{t}=1$ in the equation below: 
$\sqrt{\left(1-\rho^{2} y_{1}\right)}=\alpha \sqrt{1-\rho^{2}}+\left(\sqrt{1-\rho^{2} X_{1}}\right) \beta+\sqrt{1-\rho^{2} \mathbf{e}_{1}}$

Then, the estimation of the MCO is made.

According to Patrick Sevestre (2002), "In taking up the suggestion made by Lillard and Willis (1978) in the framework of the model of composed errors, can be applied to this model the transformation proposed by PRAIS Winsten and to eliminate the autocorrelation of the disturbances, i.e. to make the estimate of a compact manner, it is more appropriate to look at the function of self-covariance of the error term considered in the above model":

$\operatorname{cov}\left(\varepsilon_{t}-\varepsilon_{t+h}\right)=\frac{\rho^{h}}{1-\rho^{2}} \quad \operatorname{pour} h=0, \pm 1, \pm 2, \ldots$

SEVESTRE has written the matrix variancecovariance $\ \boldsymbol{Z}$ as follows:

$$
\Omega=\left[\begin{array}{ccccc}
\frac{1}{1-\mu^{2}} & \frac{a}{1-\mu^{2}} & \frac{\rho^{2}}{1-\mu^{2}} & \cdots & \frac{\rho^{1}-1}{1-p^{2}} \\
\frac{\rho}{1-\rho^{2}} & \frac{1}{1-\rho^{2}} & \frac{a}{1-\rho^{2}} & \cdots & \frac{\rho^{T-2}}{1-\rho^{2}} \\
\frac{\rho^{2}}{1-\rho^{2}} & \frac{\rho}{1-p^{2}} & \frac{1}{1-\rho^{2}} & \cdots & \frac{e^{T-2}}{1-\beta^{2}} \\
\vdots & \vdots & \vdots & \ddots & \vdots \\
\frac{\rho^{T-1}}{1-\mu^{2}} & \frac{\rho^{T-2}}{1-\mu^{2}} & \frac{\rho^{T-3}}{1-\mu^{2}} & \cdots & \frac{1}{1-\mu^{2}}
\end{array}\right] .
$$

The estimate of $\boldsymbol{\rho}$ may be written as follows: $\hat{\theta}=$ $(Z \Omega-1 Z)-1(Z \Omega-1 Y)$

Where $Z$ is the matrix of observations of the independent variables $(X t, t=1,2, \ldots, T)$;

$\mathrm{Y}$ : is a vector that accumulates the observations on the dependent variable $(X T, t=1,2, \ldots, T)$;

\section{$\Theta$ : includes the parameters of the model.}

To see why the initial assumption of observation indicated by Prais-Winsten (1954) is reasonable, the general procedure for estimation of MCQG above is useful. Where the inverse of $\boldsymbol{\Omega}$ can be decomposed to $\Omega^{-1}=G^{\prime} G$; with:

$$
\mathbf{G}-\left[\begin{array}{ccccc}
\sqrt{1-\rho^{2}} & 0 & 0 & \cdots & 0 \\
-p & 1 & 0 & \cdots & 0 \\
0 & -p & 1 & \cdots & 0 \\
\vdots & \vdots & \vdots & \ddots & \vdots \\
0 & 0 & 0 & \cdots & 1
\end{array}\right] .
$$

A pre-multiplication of model with this matrix gives the transformed model of Prais-Winsten.

This section presents the results of the regressions of our model of profitability and outlines the impact of the dependent variables (ROA and ROE) on the independent variables. Four different specifications are used: (1) The base model, (2) The controls concerning the size (in terms of total assets) of the Bank; (3) The alternative measure of efficiency and (4) The ratio of liquid assets to deposits and short-term financing in replacement of the measurement of the liquidity.

This study uses multiple regressions in order to examine the factors that determine the profitability of Islamic banks. Becker, (1995) defined as: "a method of regression analysis which uses more $q$ an explanatory variable in order to predict the values of a single Dependent variable".

We used the Stata software.12 to obtain the regression and the results of the t-test. As has already been said in the previous chapters, there are different methods of analysis used by the previous research to assess the performance of the banks. Among them, we can cite the approach of cointegration, the method Prometheus, camel, multiple regression, the MCO and the models and estimators GMM. Haron and Wan (2004) in their research have used the model of Cointegration and Error correction in order to examine the factors that determine the profitability of Islamic banks. The cointegration allows the estimation of a relationship between the nonstationary variables where the cointegration of the variables simply reveals the existence of a relationship of balance in a long term.

ARTHUR Charpentieriv has defined the test of cointegration as "the analysis of the cointegration allows to identify the relationship between several variables. This concept has been introduced as early as 1974 by Engle and Newbold, under the name of "spurious regressions, "or "deceptive regressions", then formalized by Engle and Granger in 1987, and finally by Johansen in 1991 and 1995. A series is integrated of order $d$ if it is appropriate to differentiate from times before the stationnariser. "

The models of error correction (ECM), which are derivatives of the cointegration," have been introduced at the beginning of the years 80 , by Hendry in particular. These dynamic models allow you to integrate the developments in the long-term and short-term of the variables. " (Arthur Charpentier).

This model shows how this relationship of equilibrium is reached, that is to say indicates the dynamics, in the short term, of the movement toward this balance in the long term. Samad (2004) has applied the "t-test" to evaluate the statistical difference between the two types of banks. While Athanasoglou et al. (2008) have applied the method GMM in order to estimate the determinants of the profitability of Greek banks. Kosmidou (2008) has used the method of Prometheus to assess the performance of commercial banks and cooperatives in Greece.

The Prometheus method can be considered as an extension of the system of notation CAMEL, which is widely used in the assessment of the performance of banking. PROMETHEE (preference ranking organization method for enrichment Assessments) is a family of methods that multiple-criteria decision analysis developed in Belgium. Since 1983, the methods 
Table 3. Correlation Matrix: total of the sample

\begin{tabular}{lllllllll}
\hline Variable & Roa & Roe & Llpr & Ea & Cosir & Nthe & Gdp & Icc \\
\hline Roa & 1.0000 & & & & & & & \\
Roe & 0.6299 & 1.0000 & & & & & & \\
Llpr & -0.0599 & -0.0419 & 1.0000 & & & & & \\
Ea & 0.2688 & -0.0558 & -0.1044 & 1.0000 & & & & \\
Cosir & -0.3098 & -0.2962 & 0.0300 & -0.0446 & 1.0000 & & & \\
Nthe & 0.1207 & 0.1735 & 0.0541 & -0.2047 & 0.3404 & 1.0000 & & \\
Gdp & -0.0838 & -0.0142 & 0.1810 & -0.0832 & 0.2394 & 0.1700 & 1.0000 & \\
Icc & 0.1211 & 0.0674 & -0.0761 & 0.1115 & -0.116 & -0.0649 & -0.0555 & 1.0000 \\
\hline
\end{tabular}

PROMETHEE have experienced many developments in the initiative of their authors Jean-Pierre Brans and Bertrand Mareschal of the Free University of Brussels and of the Vrije University of Brussels. PROMETHEE is a prescriptive approach to analyze multi-criteria of a problem with a number of actions (or decisions) assessed according to several criteria. It is associated with the descriptive approach, which allows you to view the conflict and the synergies between criteria, GAIA : geometrical analysis for Interactive Aid.

We note that according to the table 3 , there is a strong correlation (63\%) between the two performance variables (the ROA and the ROE). Table 3 presents a matrix symmetric square which describes the correlation between the variables in this study. A correlation matrix is similar to a covariance matrix.

The ratio of equity on total assets (EA) has a significant relationship with the Variables COSR, GDP and ROE and are all statistically significant at a level of $5 \%$. The greatest strength of the observed correlation is marked between ROA and the ratio of the ROE.

The variable COSR (Cost to Income Ratio = Total Cost / Total Assets) which refers to the effectiveness of the firm is significantly negative for the EA. Most of the other variables have a negative relationship with COSR, including the two measures of profitability, ROA and ROE. This is consistent with the obtained results by Heffernan and $\mathrm{Fu}$ (2008). There is a positive relationship between the variable (NLA) and the two Profitability Ratios ROE and ROA. Also, there is a link between the (LLR) and the ratio (COSR) and a negative relationship between COSR variable and the ratio (EA). This suggests an increase in the liquidity. Besides, the NLA is negatively correlated to EA and ICC.

The growth of the gross domestic product (GDP) has an effect on many factors related to the supply and the demand for loans and deposits. Concerning the correlation matrix, we find that the GDP has an inverse relationship with most of the variables such as ROA, ROE, EA and ICC, while it is positively correlated with the
LLR COSR and NLA. This is consistent with the study of Kosmidou (2008); who said that the GDP has a negative impact on the ROA.

The variable of inflation, which is represented by the consumer price index $(\mathrm{CPI})$, has a positive effect on the ROA, ROE and EA and a negative effect on the other variables.

The link between the ratio of return on assets $(R O A)$ is positive with EA, ROA and the index of inflation. The most important correlation coefficient is noted between the two Profitability Ratios ROA and ROE.

The descriptive statistics for the data reviewed in this analysis are presented in table 4 . The average, the gap type as well as the min and the max for each variable are shown in table 4 . The average displayed is the average value of the independent variables during the period 2005-2011. The total number of panel data is balanced in 1288.

The average is described as a measure of the central position and the gap-type is a more precise measurement of the dispersion in the measure where all data are taken into account. In return, it is sensitive to extreme values (Michel Tenenhaus, $p$ 15). The higher the gap type is the more important range (difference between maximum and minimum values) of values within the sample is the important.

The average of the dependent variables ROA and ROE are 2.22 and $13,001 \%$ respectively. For variances-types the values are respectively 4.86 and $20.20 \%$. Six independent variables are selected for this study. This includes internal and external variables.

The LLR variable (loans loss reserves or reserves for losses on loans) is used to represent the quality of the assets. The average of LLR in the data is of USD 97607,45 . The ratio (EA) is used in this study as a measure of the adequacy of the capital. The average for this variable is $19.25 \%$ and its standard deviation is $18.80 \%$. The variable (COSR) provides information on the effectiveness of the management with regard to the expenditure in relation to the revenues that it generates. 
Table 4. Descriptive Statistics

\begin{tabular}{|c|c|c|c|c|c|c|}
\hline The variables & & Mean & Std. Dev. & Min & Max & Comments \\
\hline \multirow{3}{*}{ Roa } & Overall & \multirow{3}{*}{2.215945} & 4.85944 & -30.07 & 53.09 & \multirow{3}{*}{$\begin{array}{l}N=1288 \\
N=184 \\
T=7\end{array}$} \\
\hline & Between & & 2.461678 & -7.027143 & 12.26667 & \\
\hline & Within & & 4.193173 & -30.31423 & 55.16012 & \\
\hline \multirow{3}{*}{ Roe } & Overall & \multirow{3}{*}{13.00123} & 20.20082 & -199.92 & 229.428 & \multirow{3}{*}{$\begin{array}{l}N=1288 \\
N=184 \\
T=7\end{array}$} \\
\hline & Between & & 13.3816 & -47.39371 & 85.13086 & \\
\hline & Within & & 15.16065 & -162.3188 & 157.2984 & \\
\hline \multirow{3}{*}{ LIpr } & Overall & \multirow{3}{*}{97607.45} & 403993 & -69000 & 8047320 & \multirow{3}{*}{$\begin{array}{l}\mathrm{N}=1288 \\
\mathrm{~N}=184 \\
\mathrm{~T}=7\end{array}$} \\
\hline & Between & & 249952.9 & -2141.429 & 2402237 & \\
\hline & Within & & 317847 & -2233424 & 5742691 & \\
\hline \multirow{3}{*}{ Ea } & Overall & \multirow{3}{*}{19.24635} & 18.80487 & -12.5674 & 287.398 & \multirow{3}{*}{$\begin{array}{l}N=1288 \\
N=184 \\
T=7\end{array}$} \\
\hline & Between & & 16.02897 & 2.659984 & 93.92356 & \\
\hline & Within & & 9.894428 & -30.70044 & 252.6949 & \\
\hline \multirow{3}{*}{ Cosir } & Overall & \multirow{3}{*}{60.36735} & 66.06814 & 0 & 754.0467 & \multirow{3}{*}{$\begin{array}{l}N=1288 \\
N=184 \\
T=7\end{array}$} \\
\hline & Between & & 45.27981 & 3.900723 & 279.9143 & \\
\hline & Within & & 48.2115 & -178.6155 & 568.326 & \\
\hline \multirow{3}{*}{ Nthe } & Overall & \multirow{3}{*}{51.36035} & 35.07693 & -5.805 & 578.6367 & \multirow{3}{*}{$\begin{array}{l}N=1288 \\
N=184 \\
T=7\end{array}$} \\
\hline & Between & & 23.70127 & 0 & 188.0638 & \\
\hline & Within & & 25.90895 & -110.6735 & 441.9333 & \\
\hline \multirow{3}{*}{ Gdp } & Overall & \multirow{3}{*}{17.2082} & 34.12723 & 0 & 194.1008 & \multirow{3}{*}{$\begin{array}{l}N=1288 \\
N=184 \\
T=7\end{array}$} \\
\hline & Between & & 17.91836 & 79.60953 & 140.5491 & \\
\hline & Within & & 29.07069 & 7.387712 & 173.6929 & \\
\hline \multirow{3}{*}{ Icc } & Overall & \multirow{3}{*}{5.136729} & 4.362921 & -10.47967 & 18.8 & \multirow{3}{*}{$\begin{array}{l}N=1288 \\
N=184 \\
T=7\end{array}$} \\
\hline & Between & & 2.578486 & 2.405289 & 17.18571 & \\
\hline & Within & & 3.523869 & -7.748229 & 11.76638 & \\
\hline
\end{tabular}

The average value for COSR is $60,37 \%$ and its standard deviation is estimated to a value of $66.06 \%$. The NLA is defined as net loans to total assets. It is a liquidity ratio that represents the percentage of the assets that comprise the portfolio of loans. Its average value is $51.36 \%$ and the standard deviation is $35.07 \%$. The GDP is a macroeconomic variable and is only a sign of the growth of the gross domestic product. Its average and its standard deviation are worth 17.21 and $34.13 \%$ respectively. The Consumer Price Index (CPI) which indicates the inflation, has an average of $5.14 \%$ and $4.36 \%$ for the standard deviation.

\section{Results for the indicator ROA}

Table 5 indicates the results found during the estimation of our model taking into account the ratio ROA as an explanatory variable.

We note first of all that the explanatory variables in our model are delayed for a period which greatly reduces the possibility that they are endogenous to the measures of profitability. Our model of profitability is estimated by using the technique of estimating Prais-Winston which produces an estimate by the method of correction of standard error ${ }^{v}$ from linear panel data. During the calculation of the gap-type and the matrix variancecovariance, the disturbances are assumed to be heterosedastic and simultaneously correlated. The results found during our estimation are described in table 6 . The following table presents the results found when one we take the $(R O A)$ as an explanatory variable. Three variables are significantly related with ROA: EA, COSR and GDP. $R^{2}$ is a value of 0.2545 , which means that ROA represents almost $26 \%$ of the whole sample. The constant is a negative value, it is equal to $-0.26 \%$.

The results found show that the variable (EA) has an important value and brings a significantly positive in the regression of the profitability of Islamic banks. Therefore, our results support the hypothesis $\mathrm{H} 1$ which says that the higher the ratio of own funds on assets, the more is the need for outside financing; which leads to the profitability 
Table 5. The result of estimation by the method $\mathrm{MCO}^{\mathrm{vi}}$ : Total of the sample

\begin{tabular}{|c|c|c|c|c|c|c|}
\hline Source & SS & Df & \multirow{4}{*}{\multicolumn{2}{|c|}{$\begin{array}{l}\text { MS } \\
1282.14884 \\
17.6869881\end{array}$}} & \multirow{4}{*}{\multicolumn{2}{|c|}{$\begin{array}{l}\text { Number of Obs }=1288 \\
F(6,1274)=71.70 \\
\text { Prob }>F=0.0000 \\
\text { R-Squared }=0.2545 \\
\text { Wo r-squared }=0.2510 \\
\text { Root MSE }=4.2056\end{array}$}} \\
\hline Model & 7692.89305 & 6 & & & & \\
\hline Residual & 22533.2228 & 1274 & & & & \\
\hline Total & 30226.1159 & 1280 & & & & \\
\hline Roa & Coef. & Std. Err. & $\bar{T}$ & $\mathrm{P}>|\mathrm{T}|$ & \multicolumn{2}{|c|}{ [95\% Conf.Interval] } \\
\hline Llpr & $-3.26 \mathrm{E}-07$ & $2.98 \mathrm{e}-07$ & -1.10 & 0.273 & $-9.10 \mathrm{E}-07$ & $4.22 \mathrm{e}-07$ \\
\hline Ea & 0.0794388 & 0.006454 & 12.31 & 0.000 & 0.0667773 & 0.0921004 \\
\hline Cosir & -0.0291822 & 0.0019408 & -15.04 & 0.000 & -0.0329898 & -0.0253746 \\
\hline Nthe & 0.0451311 & 0.003652 & 12.36 & 0.000 & 0.0379664 & 0.0522958 \\
\hline Gdp & -0.001485 & 0.0036238 & -0.41 & 0.682 & -0.0085943 & 0.0056242 \\
\hline IcC & 0.0660424 & 0.0273387 & 2.42 & 0.016 & 0.0124086 & 0.1196762 \\
\hline Cons & -0.0026038 & 0.492957 & -0.01 & 0.996 & -0.9697005 & 0.9644928 \\
\hline
\end{tabular}

of the Bank. This result is consistent with previous studies (Demirguc-Kunt and Huizinga, 1999; Kosmidou and al, 2006, Pasiouras and al, 2006; Athanasoglou and al, 2008; Heffernan and Fu, 2008). According to the results of this model the coefficient (NLA) is significant at the level of $5 \%$ on the whole of the sample. Therefore, bank liquidity appears to be a determining factor of the banking profitability.

We note from these results that the coefficient of LLR has a negative sign which is unexpected and is not significant. Therefore, the results do not support our hypothesis $\mathrm{H} 2$ which stipulates that this ratio of reserves for losses on loans (LLR) is positively correlated with the profitability.

As expected, the coefficient of COSR seems to be negative and significant at the level of $1 \%$, which suggests that the effectiveness in the management of expenditure is a robust determinant of profits for Islamic banks. This result confirms the hypothesis H3 which asserts that the cost and income are negatively related to the profitability of Islamic banks. Kosmidou et al. (2006) of same Pasiouras et al. (2006) also confirm this inverse relationship in their studies, respectively, on the United Kingdom and European banks.

Regarding to the external determinants of the profitability, table 6 shows that the growth of the GDP is significantly related to the profitability of conventional banks.

However, the coefficient of inflation is significantly positive at $5 \%$, for the whole of the sample. This last result is similar with the studies of (Athanasoglou and al, 2008; Kosmidou and al, 2006; Pasiouras and al, 2007 and Demirguc-Kunt and Huizinga, 1999) and confirms the hypothesis $\mathrm{H} 6$ which says that high rates of inflation are generally associated with high rates of interest on loans, which lead to a higher banking profitability (Hassan and Bashir, 2003).

Our model is written as follows:

$R 0 A=0.4588247-4.05 \mathrm{e}^{-7}($ LLR $)+0.0810508(E A)-0.0329554($ COSR $)$ $+0.0516357($ NLA $)-.0050595(G D P)+0.0544503(C P I)$

\section{Results for the indicator ROE}

ROE is the ratio of the "net income after tax of the Bank divided by its total capital in actions" (Rose, 2002). The performance its equity (ROE) is considered as one of the ratios of performance and profitability ( Tarawneh , 2006). It indicates to what extent the management of the enterprise is capable of transforming of own funds ${ }^{\text {vii }}$ in the net profit. It is the rate of return that relates to the shareholders of The Bank ( Samad, 1999). When the ROA and ROE is higher, it reflects the efficiency of the management of the Bank.

Several empirical studies have focused on the comparison of the profitability of Islamic banks and conventional banks ones. Some works reveal that the Islamic banks are more profitable compared to conventional banks (Olson and Zoubi, 2008; Hassoune, 2002; Iqbal, 2001; Rosly and Bakar, 2003). However, other empirical studies found different results (Metwally, 1997; Ahmed and Hassan, 2007; Kader and Asarpota, 2007). Olson and ZOUBI (2008) compared 28 conventional banks to 16 Islamic ones in the Gulf region for the period 2000-2005. Their study confirms that the Islamic banks are more profitable and shows that the profitability of the assets and the profitability of equity are significantly higher in Islamic banks. The ratio of net margin is two times higher for the Islamic banks compared to conventional ones, and the difference is significant. Their study, also, reveals that the Islamic banks pay to their shareholders of dividends is more 
Table 6. Results of the estimation by the method Prais-Winston: Total of the sample

\begin{tabular}{|c|c|c|c|c|c|c|}
\hline \multicolumn{7}{|c|}{ Prais-Winsten regression, correlated panels standard corrected errors (PCSEs) } \\
\hline \multicolumn{7}{|c|}{$\begin{array}{l}\text { Variable Group: Bank Number of Obs }=1288 \\
\text { Time variable: Year Number of groups }=184 \\
\text { Panels: correlated (balanced) OBS per group: } \min =7 \\
\text { Autocorrelation: Panel-specific AR(1) avg }=7 \\
\qquad \operatorname{Max}=7 \\
\text { Estimated covariances }=16836 \text { R-Squared }=0.3332 \\
\text { Estimated autocorrelations }=183 \text { Wald Chi2 } 2(6)=336.27 \\
\text { Estimated coefficients }=7 \text { PROB }>\text { Chi2 }=0.0000\end{array}$} \\
\hline \multicolumn{7}{|c|}{ Panel-corrected } \\
\hline Roa & Coef. & Std. Err. & Z & $\mathrm{P}>|\mathrm{z}|$ & [95\% Conf.In & val] \\
\hline Llpr & $-4.05 \mathrm{E}-07$ & $1.36 \mathrm{e}-07$ & -2.98 & 0.003 & $-6.71 E-07$ & $-1.39 \mathrm{E}-07$ \\
\hline $\mathrm{Ea}$ & 0.0810508 & 0.0220235 & 3.68 & 0.000 & 0.0378855 & 0.1242161 \\
\hline Cosir & -0.0329554 & 0.0023107 & -14.26 & 0.000 & -0.0374843 & -0.0284264 \\
\hline Nthe & 0.0516357 & 0.0066772 & 7.73 & 0.000 & .0385486 & 0.0647228 \\
\hline Gdp & -0.0050595 & 0.0028152 & -1.80 & $\begin{array}{l}\text { Execution } \\
\text { time: } 0.066\end{array}$ & -0.0105772 & 0.0004582 \\
\hline IcC & 0.0544503 & 0.0308781 & 1.76 & 0.078 & -0.0060697 & 0.1149702 \\
\hline _Cons & 0.4588247 & 0.7279992 & 0.63 & $\begin{array}{l}\text { Execution } \\
\text { time: } 0.541\end{array}$ & -0.9680274 & 1.885677 \\
\hline Rhos & 0.5175012 & 0.9107468 & 1 & 0.8477848 & 1 & 1 \\
\hline
\end{tabular}

Source: Estimated Results with STATA.12

important compared to their conventional counterparts. The study of lqbal (2001) revealed that the Islamic banks record higher profitability of own capital and profitability of assets compared to a reference sample of conventional banks for the period 1990-1998. The study focused on 24 Islamic banks; 12 are from 10 different countries. The study conducted by Rosly and Bakar (2003) has also shown that the profitability of the assets and the profit margin of Islamic banks are higher in Malaysia during the period 1996-1999. viii

However, other empirical studies found different results (Metwally, 1997; Ahmed and Hassan, 2007; Kader and Asarpota, 2007). Metwally (1997) compared 30 banks, 15 are Islamic during the period 1992-1994. Its results reveal that the Islamic banks do not seem to be very different from their conventional counterparts in terms of profitability of assets and the rate of return on the deposits. The two types of banks offer equivalent returns to their constituencies. Olson and ZOUBI (2008) have shown that the expected returns are similar to those offered on the conventional deposits of same maturity knowing that the rates of returns on the Islamic deposits should depend on future profits. Ahmed and Hassan (2007) have also shown that the activity Islamic banking as well as conventional generate ones a profitability of capital and a profitability of similar assets in Bangladesh. Kader and Asarpota (2007) have shown that the Islamic banks in the United Arab Emirates generate a lower profitability of capital own in the period 2000-2004. The determinants of the profitability of banks have long been a major axis of research in many countries. These studies have focused on the two categories of banks, the Islamic (Srairi, 2008; Sanusi and Ismail, 2005; Bashir and Hassan, 2003; Bashir, 2003; Sudin, 1996) and conventional (Olson and Zoubi, 2011; Dietrich and Wanzenried, 2011; Athanasoglou and al, 2008; Rouisi and al, 2008; Srairi, 2008; Pasiouras and Kosmidou, 2007; Ben Naceur and Goaied, 2003).

Even the role of Islamic banks in the area of financial stability has already been analyzed in 18 countries, between 1993 and 2004 (Čihák and Hessen, 2008). They analyze the financial stability by using the z-score. Their results indicate an interesting difference in the stability of small and large Islamic banking institutions. It has been found that the smaller banks have proved to be much more stable than those operating at a larger scale. The proposed explanation is that the Islamic banks tend to have difficulties in the monitoring of credit risk when the company becomes larger and therefore more complex. The limits of this management of credit risk on a larger scale means problems of moral hazard. The small banks have a tendency to concentrate on low-risk investments, while the large Islamic banks perform more risky financing (PLS). Table 7 and 8 show us the results found during the estimation of our empirical model while taking into account the ratio ROE as an explanatory variable.

The results of table 8 show that the coefficient (EA) is negative but not significant for the conventional banks 
Table 7. The result of estimation by the OLS method

\begin{tabular}{|c|c|c|c|c|c|c|}
\hline Source & SS & Df & MS & & \multirow{4}{*}{\multicolumn{2}{|c|}{$\begin{array}{l}\text { Number of Obs }=1288 \\
F(6,1274)=46.08 \\
\text { Prob }>F=0.0000 \\
\text { R-Squared }=0.1783 \\
\text { Wo r-squared }=0.1745 \\
\text { Root MSE }=18.354 \\
\text { Root MSE }=4.2056\end{array}$}} \\
\hline Model & 93147.6891 & 6 & \multirow{3}{*}{\multicolumn{2}{|c|}{$\begin{array}{l}15524.6149 \\
336.880422 \\
408.072927\end{array}$}} & & \\
\hline Residual & 429185.657 & 1274 & & & & \\
\hline Total & 522333.347 & 1280 & & & & \\
\hline Roa & Coef. & Std. Err. & $\mathbf{T}$ & $P>|T|$ & [95\% Conf.I & rval] \\
\hline LIpr & $-2.62 \mathrm{E}-06$ & $1.30 \mathrm{e}-06$ & -2.02 & 0.044 & $-5.17 \mathrm{E}-06$ & $-7.55 \mathrm{E}-08$ \\
\hline Ea & -0.0191307 & 0.0281668 & -0.68 & 0.497 & -0.0743892 & 0.0361277 \\
\hline Cosir & -0.1237463 & 0.0084703 & -14.61 & 0.000 & -0.1403637 & -0.107129 \\
\hline Nthe & 0.1762997 & 0.0159385 & 11.06 & 0.000 & 0.1450311 & 0.2075683 \\
\hline Gdp & 0.0241987 & 0.0158152 & 1.53 & 0.126 & -0.006828 & 0.0552254 \\
\hline Icc & 0.1879733 & 0.1193133 & 1.58 & 0.115 & -0.0460989 & 0.4220454 \\
\hline Cons & 8.239144 & 2.151394 & 3.83 & 0.000 & 4.01848 & 12.45981 \\
\hline
\end{tabular}

Table 8. Results of the estimation by the method Prais-Winston: Total of the sample

\begin{tabular}{|c|c|c|c|c|c|c|}
\hline \multirow{2}{*}{\multicolumn{7}{|c|}{ 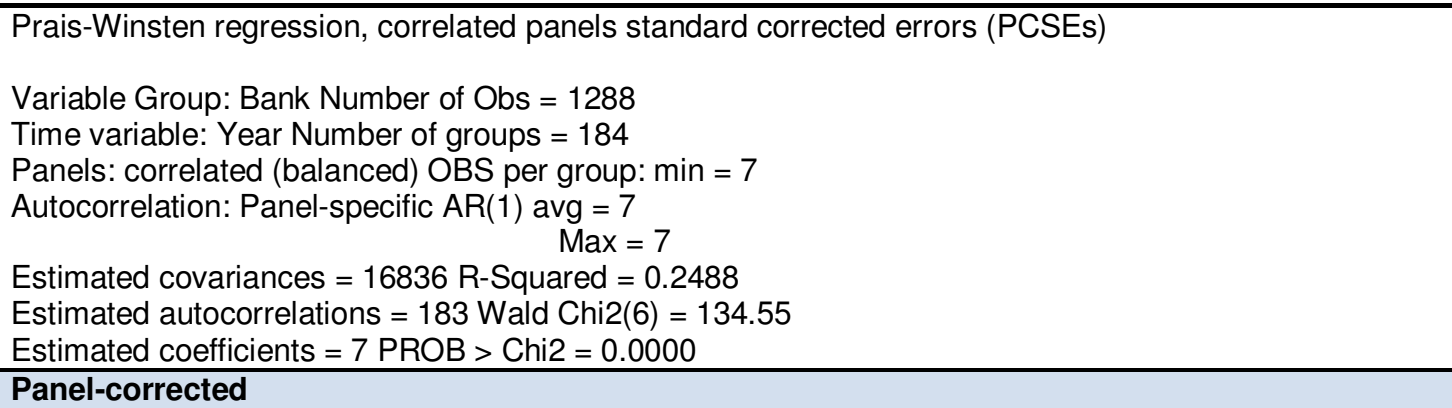 }} \\
\hline & & & & & & \\
\hline \multirow{2}{*}{$\begin{array}{l}\text { Roa } \\
\text { LIpr }\end{array}$} & \multirow{2}{*}{$\begin{array}{l}\text { Coef. } \\
-2.23 \mathrm{E}-06\end{array}$} & \multirow{2}{*}{$\begin{array}{l}\text { Std. Err. } \\
8.20 \mathrm{e}-07\end{array}$} & & \multirow{2}{*}{$\begin{array}{l}\mathbf{P}>|\mathbf{z}| \\
0.007\end{array}$} & \multicolumn{2}{|c|}{ [95\% Conf.Interval] } \\
\hline & & & & & $-3.83 E-06$ & $-6.18 \mathrm{E}-07$ \\
\hline $\mathrm{Ea}$ & 0.0282099 & 0.0623152 & 0.45 & 0.651 & -0.0939257 & 0.1503454 \\
\hline Cosir & -0.1194376 & 0.0159027 & -7.51 & 0.000 & -0.1506064 & -0.0882688 \\
\hline Nthe & 0.2010957 & 0.0207873 & 9.67 & 0.000 & 0.1603534 & 0.2418381 \\
\hline Gdp & 0.0039743 & 0.0132549 & 0.30 & 0.764 & -0.0220048 & 0.0299534 \\
\hline Icc & 0.1261897 & 0.1229959 & 1.03 & 0.305 & -0.1148778 & 0.3672572 \\
\hline Cons & 7.787607 & 2.39711 & 3.25 & 0.001 & 3.089358 & 12.48586 \\
\hline Rhos & 0.3973019 & 0.7304899 & 0.94769 & 0.4265794 & -0.0255404 & 1 \\
\hline
\end{tabular}

(it is equal to $0,879>0.05)$, which is not the case for the Islamic Banks (Athanasoglou et al. (2008)). As expected, the coefficient Nthe is positive and significant at the $5 \%$ threshold. We reject, therefore, the hypothesis $\mathrm{H} 4$ which stipulates that the NLA has a negative impact on the profitability of banks.

According to the table of results estimated by the method Prais Winston, the variable (LLR) is significant and negatively related to profitability. This contradicts with the hypothesis $\mathrm{H} 3$. This leads to reduce the income interest and increase the costs of provisioning the bank (Kosmidou et al., 2006). In accordance with our previous results, the coefficient (COSR) is negative and statistically significant at the $1 \%$ level on the whole of the sample. As well, the effectiveness is considered one of the determinants of the performance of Islamic banks. 
While the inflation positively affects and not significantly the profitability, we are announcing, in this case, a non significant relationship between GDP growth and profitability.

As indicated in the previous table, two independent variables are important in this regression model: the (COSR) and the growth of ratio of inflation (ICC). Product COSR the $t$ value the highest among all the variables of these two models of profitability that is 14.26. The explanatory power of ROE which is indicated by $R$ square is $25 \%$. The value of the constant for this model is 7,787 . Where our model will be as follows:

$R O E=7.787607-2.23 . \mathrm{e}^{-6}(L L R)+0.0282099(E A)-0.1194376(C O S R)+0.2010957(N L A)$ $+0.0039743($ GDP $)+0.1261897(C P I)$

\section{Conclusion}

The recent rapid growth in the Islamic banking sector has attracted the interest of researchers to better understand the determinants of Islamic bank profitability. In this article, we have examined this problem by using a set composed of 184 banks, of which 52 are conventional and 132 are Islamic, operating in the MENA region between 2005 and 2011. More specifically, we have considered the impact of efficiency, the capital, the quality of the assets and the liquidity on the profitability of Islamic and conventional banks. After analyzing the factors determining the profitability of banking and the macroeconomic environment, we find the elements supporting our main assumptions. More specifically, we find that the strength of the capital, measured by the ratio (EA) is significantly and positively related to ROA. This provides support to our hypothesis $\mathrm{H}_{1}$, stipulating that the well capitalized banks are faced with a reduction of costs of external financing, which reduces costs and improves the profits (Demirguc-Kunt and Huizinga, 1999; Kosmidou and al, 2006; Pasiouras and al, 2006; Athanasoglou and al, 2008; Heffernan and Fu, 2008). The results found show that the effectiveness is linked with the ratio (COSR), and negatively affects the profitability of the Islamic Bank in a significant way, and seems to be the most important determinant of this profitability. In accordance with our hypothesis $\mathrm{H} 3$, this conclusion is in agreement with previous studies, as Pasiouras (2007), Kosmidou et al. (2005), and Kosmidou et al. (2006).

In addition, the impact of liquidity on the performance of the Bank varies depending on the measure of profitability used. More specifically, the liquidity is not significantly related to ROA and ROE. These results provide partial support for hypothesis $\mathrm{H} 4$ and indicate that the high NLA ratios may reduce the liquidity and increase the number of borrowers marginal, which reduces the performance of the bank (Demirguc-Kunt and Huizinga, 1999). The impact of the quality of the assets, measured with reserves for losses on loans (LLR), is positive and significant. This conclusion, in contradiction with the hypothesis $\mathrm{H} 3$, could be explained by the fact that these ratios are high. It may indicate a poor quality of loans, which could reduce the interest income and increase the costs of provisioning the bank (Kosmidou et al., 2006).

Finally, it is deduced that the macro-economic environment is favorable ( the growth of GDP and inflation) and seems to stimulate higher profits. This is similar to the conventional banks, where the growth of GDP and inflation have been found positively significant with the ratios of the banking performance.

On the whole, the similarity between the Profitability determinants results between the traditional Islamic banks clearly indicates that the techniques and the tools developed in the literature on the conventional banking services are potentially applicable to a Islamic banking system.

\section{References}

Bashir A-HM (1999). "Risk and Profitability measures in Islamic Banks: The Case of two Sudanese banks", Islamic Econ. Studies. 6: 1-24.

Hasan M, Dridi J (2010). the effects of global crisis there Islamic and conventional banks: a comparative study, IMF Working Paper 10/201.

Hassan MK, Bashir AM (2003)" Determinants of Islamic banking profitability," ERF paper

Hassan MK, Samad M, Islam MM (2003). "The performance evaluation of the Bahraini banking system". University of New Orleans: Working Paper.

Salman SA (2011). "Islamic Banking in the MENA region" the World Bank, Islamic Development Bank - Islamic Research and Training Institute.

Samad A, Hassan M (2001). the performance of Malaysian Islamic Bank During 1984 -1997: Year explanatory study, Economics, 10 (1and2): 7-26.

Samad A, Hassan MK (1999). "The performance of Malaysian Islamic Bank during 1984-1997: An Exploratory Study", International Journal of Islamic Financial Services, 1.

\section{Endnotes}

I. Kuwait, UAE, Bahrain, Jordan, Egypt, Turkey, Bangladesh, Qatar, Malaysia, Saudi Arabia

II. Hasan.M and Dridi.I, (2010): "Put to the test: Islamic banks have better resisted to the crisis that the conventional banks", Finance and Development, December 2010, pp46-47.

III. SALMAN Syed Ali, (2011): "Islamic Banking in the MENA region" the World Bank, Islamic Development Bank - Islamic Research and Training Institute.

IV. http://perso.univ-rennes1.fr/arthur.charpentier/TS2.pdf

V. $\quad$ If the residue is stationary we can estimate a model called model of correction of errors (ERM), which incorporates the variables in variation and level (the theorem of the representation of Granger highlights the link between cointegration and model to correction of error). The employment of a model to correction of error in the case of the cointegration allows to obtain more reliable forecasts than if we had used the long-term relationship because the results of the estimation of this relationship are distorted by the nonstationarity of the series." Hélène HAMUSULTANE (http://helenehamisultane.voila.net/travaux/MCE.pdf).

VI. The presence of heteroskedasticity and autocorrelation $===>$ The use of OLS can biais the results of estimation $===>$ We use the technique of Prais-Winston in order to correct these problems 
C.-to-equity, "it is to meet the basic needs of humanity in housing, food, health and education, reducing inequalities between individuals, in the respect of their cultures ".
Kuwait, UAE, Bahrain, Jordan, Egypt, Turkey, Bangladesh, Qatar, Malaysia, Saudi Arabia 